\title{
Synthesis, Spectral Studies and Antibacterial Activities of 8-Hydroxyquinoline Derivative and its Metal Complexes
}

\author{
S. S. SYED ABUTHAHIR ${ }^{1}$ A. JAMAL ABDUL NASSER ${ }^{1}$, S. RAJENDRAN ${ }^{2 *}$ \\ and G. BRINDHA ${ }^{2}$
}

${ }^{1}$ PG \& Research Department of Chemistry, Jamal Mohamed College,

Tiruchirappalli-620 020, India

${ }^{2}$ Department of Chemistry, RVS School of Engineering and Technology,

Dindigul-624 005, India

srmjoany@sify.com

Received 7 May 2013 / Accepted 7 June 2013

\begin{abstract}
Hydroxy quinolin-2yl-methyl) thiourea ligand (HTF) was synthesized from 8 -hydroxyquinoline and thiourea with formaldehyde by condensation method in $N, N$-dimethyl foramide medium. The metal complexes $\mathrm{Zn}(\mathrm{II}), \mathrm{Cu}(\mathrm{II}), \mathrm{Ni}(\mathrm{II})$ and $\mathrm{Co}(\mathrm{II})$ were prepared using the 1-(8-hydroxy quinolin-2yl-methyl) thiourea as ligand. The ligand and its metal complexes were characterized by elemental analysis, FT-IR, UV-Visible, cyclic voltammetry, Mass spectra and NMR spectroscopy. The ligand and its metal complexes possess antibacterial activity for certain bacteria such as Staphylococcus aureus, Escherichia coli, Pseudomona aeruginosa and C.tropicalis.
\end{abstract}

Keywords: 8-Hydroxyquinoline derivative, Antibacterial screening, Thiourea derivative, Cyclic Voltammetry

\section{Introduction}

8-Hydroxyquinoline is a long known molecule which due to its metal complexation ability frequently is used for analysis or metal precipitation ${ }^{1}$. Recently aluminum complexes with 8-hydroxyquinoline derived ligands were introduced as molecular components for organic light emitting diodes ${ }^{2}$. Zinc(II) complexes show luminescence as well, which typically is red shifted compared to the corresponding Al(III) compounds ${ }^{3}$. The coordination chemistry of simple 8-hydroxyquinolines with zinc(II) ions is very versatile. Although mainly 2:1 complexes are obtained, 3:1 complexes can also be formed ${ }^{4}$. In case of 2:1 complexes different structures could be observed in the solid state. For example, with unsubstituted 8-hydroxyquinoline an octahedral compound was obtained which bears two water molecules binding trans to a square planar bis(quinolinato) zinc moiety ${ }^{5}$. The anhydrous 8 -hydroxyquinolinate complex of zinc(II) is made up from four 2:1 complex units which are connected by bridging quinolinate oxygen atoms ${ }^{6}$. Recently the trinuclear zinc complex was described which possesses some interesting photophysical properties. Liphophilic 8-hydroxyquinoline 
derivatives (like the commercially available kelex 100$)^{7}$ are used for metal extraction purposes. On the other hand sterically less demanding 7-nonyl-8-hydroxyquinoline forms a dimeric complex with pentacoordinated zinc atoms ${ }^{8}$. Recently the groups of pierre, Secrratrice, Bradshaw and Hiratani developed di and tritopic 8-hydroxyquinoline derivatives for the selective extraction or sensitizing of metal ions 9 . In supramolecular chemistry of 8-hydroxyquinoline derivatives can be used for the formation of hydrogen bonded networks ${ }^{10,11}$ as well as of metallo-supramolecular aggregates ${ }^{4}$. To manipulate the self-assembly properties of the 8-hydroxyquinoline derivatives we recently introduced amide or urea substituents as additional hydrogen bond donor/acceptor units ${ }^{11}$. Here hierarchical selfassembly ${ }^{12}$ can take place leading first to an 8-hydroxyquinoline dimer or a metal complex. Some complexes of 8-hydroxyquinoline and its derivatives are used as the emitting elements in electroluminescent devices ${ }^{13,14}$.

In the present study 8-hydroxyquinoline derivatives and their metal complexes from thiourea and formaldehyde have been prepared and characterized by spectral studies. Their antibacterial activity has also been investigated.

\section{Experimental}

8-Hydroxyquinoline and thiourea were procured from Merck, India and purified by rectified spirit. Formaldehyde (37\%) was of AR grade. Merck and used as received. Double distilled water was used for all the experiments. All other chemicals and metal salts were of analytical grade and used without further purification.

\section{1-(8-Hydroxy quinolin-2yl-methyl)thiourea}

The compound was synthesized by the refluxation of 8 -hydroxyquinoline $(0.1$ mole $)$ with thiourea $(0.1 \mathrm{~mole})$ and formaldehyde $(0.1 \mathrm{~mole})$ using dimethyl formamide as the reaction medium at $60{ }^{\circ} \mathrm{C}$ for $6 \mathrm{~h}$. The reaction mixture was then cooled, poured into crushed ice with constant stirring and kept in refrigerator overnight. The yellow colour precipitate was formed and separated out. The separated precipitate was several times washed with water and dried. The compound was recrystallised using ethanol. The yield of the compound was found $92.75 \%$ and the reaction route was shown in Scheme 1.

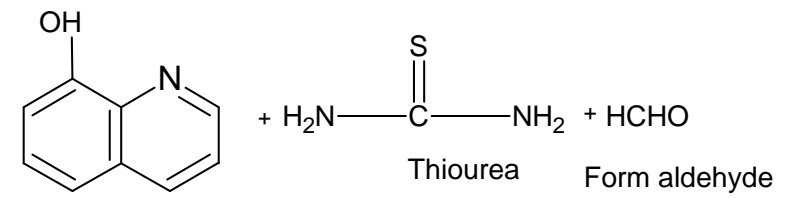

8-Hydroxyquinoline
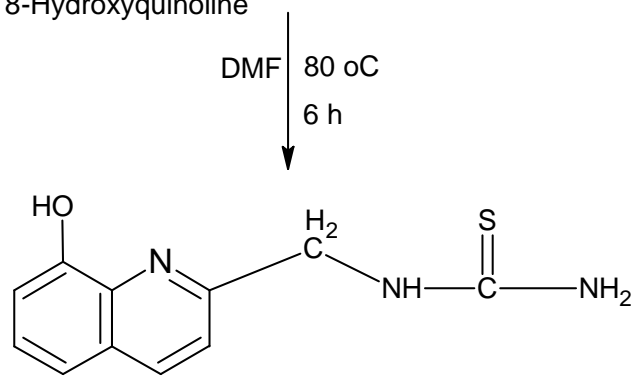

8-(Hydroxy-quinolin-2-ylmethyl)-thiourea HTF ligand

Scheme 1. Reaction route of HTF ligand 


\section{Synthesis of metal complexes}

The ligand ( 0.1 mole) was dissolved in ethanol and the metal nitrates of $\mathrm{Zn}(\mathrm{II}), \mathrm{Cu}$ (II) (0.1 mole) and metal chlorides of $\mathrm{Ni}(\mathrm{II}), \mathrm{Co}$ (II) $(0.1 \mathrm{~mole})$ were dissolved separately in ethanol and filtered off. The resultant solution were mixed together with constant stirring and refluxed for $3 \mathrm{~h}$. The organic metal complexes obtained were separated and washed with water. Moreover the organic metal complexes were dried in an air oven at $40{ }^{\circ} \mathrm{C}$ for $3 \mathrm{~h}$. The reaction scheme for the preparation of the organic metal complexes is shown in Scheme 2.<smiles>NC(=S)NCc1ccc2cccc(O)c2n1</smiles>

8-(Hydroxy-quinolin-2yl-methyl)-thiourea HTF ligand

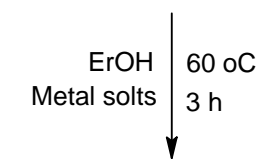

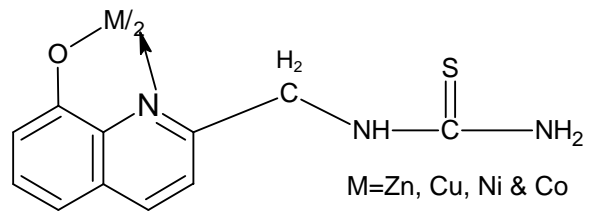

Scheme 2. Reaction route for HTF metal complexs

\section{Spectral analysis}

The elemental analysis of the compound and their metal complexes has been carried out to identify the composition of each element (Model Vario EL III, Germany). The metal contents were determines volumetrically by Vogel's methods ${ }^{15}$. The FT-IR spectrum of the synthesized ligand and their metal complexes had been scanned in $\mathrm{KBr}$ pellets on a bruker (Model Tensor 27) spectrophotometer to identify the linkages and functional groups. Cyclic Voltammetry studies have been used for the identification of various metal ions present in the complexes. The UV-Visible spectrum of the synthesized ligand and metal complexes were recorded in cary Eclipse varian (Model U.3400) UV-Visible spectrophotometer and the ${ }^{1} \mathrm{H}$ NMR spectrum using $\mathrm{CDCl}_{3}-\mathrm{d}_{6}$ solvent Bruker $400 \mathrm{MHz},{ }^{13} \mathrm{C}$ NMR spectrum was also recorded for the ligand using Bruker $100 \mathrm{MHz}$. Mass spectra were obtained using Voyager $\mathrm{DE}^{\mathrm{TM}}$ PRO Biospectrometry Workstation (Applied Biosystems). All the electrochemical measurements were carried out using conventional two compartments and three electrode electrochemical analyzer (CHI model 643B, Austin, USA)

\section{Antibacterial screening}

Biological assay depends upon a comparison of the inhibition of growth of microorganism by measuring the concentration of the sample which is to be examined with the known concentration of standard antibiotic. Disc diffusion method has involved for antibacterial activity. In this study the ligand ant its metal complexes were tested for their affect on certain human pathogenic bacterias such as Staphylococcus aureus, Escherichia coli, Pseudomona aeruginosa and C.tropicalis. 


\section{Results and Discussion}

The synthesized compound and its metal complexes were soluble in solvents like methanol, ethanol, acetone, chloroform, $\mathrm{N}$ - $\mathrm{N}$-dimethyl formamide, tetrahydrofuran and dimethyl sulphoxide. The physical and analytical data of the synthesized compound and its metal complexes are given in Table 1. Based on the analytical data the molecular formula of the synthesized ligand and its metal complexes are found to be in good agreement with the calculated elemental values of $\mathrm{C}, \mathrm{H}, \mathrm{N}$, and metal.

Table 1. Physical and analytical data of the HTF ligand and their metal complexes

\begin{tabular}{|c|c|c|c|c|c|c|c|c|c|}
\hline \multirow{2}{*}{$\begin{array}{c}\text { Empirical } \\
\text { Formula }\end{array}$} & \multirow{2}{*}{$\begin{array}{c}\text { Molecular } \\
\text { Weight }\end{array}$} & \multirow{2}{*}{ Colour } & \multicolumn{2}{|c|}{ Yield, Melting } & \multicolumn{5}{|c|}{$\%$ Found (Calculated) } \\
\hline & & & $\% \quad 1$ & Point, ${ }^{\circ} \mathrm{C}$ & $\mathrm{C}$ & $\mathrm{H}$ & $\mathrm{N}$ & $\mathrm{S}$ & M \\
\hline $\begin{array}{cl}\text { Ligand } & \mathrm{C}_{11} \mathrm{H}_{11} \\
(\mathrm{HTF}) & \mathrm{N}_{3} \mathrm{OS}\end{array}$ & 233 & $\begin{array}{l}\text { Light } \\
\text { Yellow }\end{array}$ & 92.75 & 51 & $\begin{array}{c}56.54 \\
(56.65)\end{array}$ & $\begin{array}{l}4.68 \\
(4.72)\end{array}$ & $\begin{array}{c}17.56 \\
(18.02)(\end{array}$ & $\begin{array}{c}13.65 \\
(13.73)\end{array}$ & - \\
\hline HTF-Zn $\begin{array}{c}\mathrm{C}_{11} \mathrm{H}_{10} \\
\mathrm{~N}_{3} \mathrm{OS}-\mathrm{Zn}\end{array}$ & 297.7 & yellow & 56.11 & 156 & $\begin{array}{c}44.28 \\
(44.33)\end{array}$ & $\begin{array}{l}3.57 \\
(3.69)\end{array}$ & $\begin{array}{l}13.94 \\
(14.10)(\end{array}$ & $\begin{array}{c}10.57 \\
(10.74)\end{array}$ & $\begin{array}{l}21.86 \\
(22.06)\end{array}$ \\
\hline HTF-Cu $\begin{array}{c}\mathrm{C}_{11} \mathrm{H}_{10} \\
\mathrm{~N}_{3} \mathrm{OS}-\mathrm{Cu}\end{array}$ & 295.54 & $\begin{array}{c}\text { Brownish } \\
\text { green }\end{array}$ & 62.27 & 280 & $\begin{array}{c}44.53 \\
(44.66)\end{array}$ & $\begin{array}{l}3.63 \\
(3.72)\end{array}$ & $\begin{array}{l}14.08 \\
(14.21)(\end{array}$ & $\begin{array}{l}10.38 \\
(10.82)\end{array}$ & $\begin{array}{l}21.29 \\
(21.49)\end{array}$ \\
\hline $\begin{array}{lc}\text { HTF-Ni } & \mathrm{C}_{11} \mathrm{H}_{10} \\
\mathrm{~N}_{3} \mathrm{OS}-\mathrm{Ni}\end{array}$ & 290.69 & $\begin{array}{l}\text { Light } \\
\text { green }\end{array}$ & 67.03 & 289 & $\begin{array}{c}45.23 \\
(45.40)\end{array}$ & $\begin{array}{l}3.61 \\
(3.78)\end{array}$ & $\begin{array}{c}14.32 \\
(14.44)(\end{array}$ & $\begin{array}{c}10.89 \\
(11.00)\end{array}$ & $\begin{array}{l}19.95 \\
(20.18)\end{array}$ \\
\hline HTF-Co $\begin{array}{c}\mathrm{C}_{11} \mathrm{H}_{10} \\
\mathrm{~N}_{3} \mathrm{OS}-\mathrm{Co}\end{array}$ & 290.93 & $\begin{array}{l}\text { Dark } \\
\text { green }\end{array}$ & 61.90 & 324 & $\begin{array}{r}45.32 \\
(45.37) \\
\end{array}$ & $\begin{array}{l}3.60 \\
(3.78) \\
\end{array}$ & $\begin{array}{l}14.28 \\
(14.43)( \\
\end{array}$ & $\begin{array}{c}10.84 \\
(10.99) \\
\end{array}$ & $\begin{array}{c}19.91 \\
(20.25) \\
\end{array}$ \\
\hline
\end{tabular}

\section{Spectral analysis}

FT-IR spectra are the most powerful tool for identifying the functional groups. The FT-IR spectrum of the 1-(8-hydroxy quinolin-2yl-methyl) thiourea ligand (HTF) and its metal complexes are depicted in Figure 1 and the frequency data are presented in Table 2. In the ligand spectrum a broad band appeared in the region of $3390.34 \mathrm{~cm}^{-1}$ is assigned to the hydroxyl group present in 8-hydroxyquinoline aromatic ring ${ }^{16}$. A peak appeared at $2920.55 \mathrm{~cm}^{-1}$ is assigned to $\mathrm{CH}_{2}$ group vibration in the aromatic ring. A band appeared in the region of $1571.36 \mathrm{~cm}^{-1}$ is assigned for $\mathrm{C}=\mathrm{N}$ present in aromatic ring. A strong band appeared in the range of $1382.85 \mathrm{~cm}^{-1}$ and $1127.28 \mathrm{~cm}^{-1}$ is assigned for $\mathrm{C}-\mathrm{N}$ and $\mathrm{C}=\mathrm{S}$ moiety of thiourea.

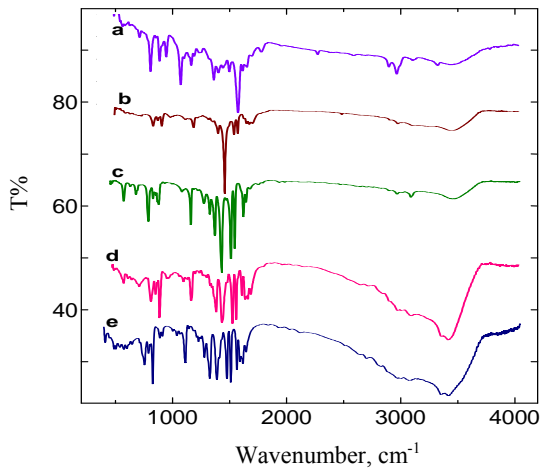

Figure 1. FT-IR spectra obtained for (a) HTF-ligand, (b) HTF-Zn, (c) HTF-Cu, (d) HTF-Ni and (e) HTF-Co complexes 
Table 2. FT-IR spectral data of the HTF ligand and their metal complexes

\begin{tabular}{ccccccc}
\hline \multicolumn{7}{c}{ Observed frequencies $\left(\mathrm{cm}^{-1}\right)$} \\
\hline Compound & $v-\mathrm{OH}$ & $\begin{array}{c}v C-N \\
\text { (aromatic) }\end{array}$ & $v \mathrm{CH}_{2}$ & $v \mathrm{C}=\mathrm{S}$ & $v \mathrm{C}=\mathrm{N}$ & $v \mathrm{C}-\mathrm{O}-\mathrm{M}$ \\
\hline HTF-ligand & 3390.34 & 1382.85 & 2920.55 & 1127.28 & 1571.36 & - \\
HTF-Zn & 3405.67 & 1384.64 & 2925.48 & 1106.94 & 1556.27 & 1033.66 \\
HTF-Cu & 3405.67 & 1384.64 & 2958.27 & 1110.8 & 1573.63 & 1033.66 \\
HTF-Ni & 3374.82 & 1375.00 & 2927.41 & 1101.15 & 1579.41 & 1033.66 \\
HTF-Co & 3343.96 & 1378.85 & 2940.91 & 1108.87 & 1577.49 & 1033.66 \\
\hline
\end{tabular}

A weak band appearing in the region $3084.93 \mathrm{~cm}^{-1}$ is attributed to $\mathrm{CH}_{2}$ linkage present in the synthesized 1-(8-hydroxy quinolin-2yl-methyl) thiourea ligand (HTF) ${ }^{17}$. In the spectra of metal complexes a sharp band appearing compared to its ligand in the region of 3300$3400 \mathrm{~cm}^{-1}$ due to the coordination of the ligand with the metal ions through the oxygen atom of phenolic group of 8-hydroxyquinoline and may also be due to the coordination of water molecules. A band appearing in the region of $1101.15-1127.28 \mathrm{~cm}^{-1}$ is assigned to $\mathrm{C}=\mathrm{S}$ stretching vibrations. The band in the range of $1033.66 \mathrm{~cm}^{-1}$ are is assigned to the C-O-M in the respective metal complexes ${ }^{18}$. The band ranges from $1375.00-1384.64 \mathrm{~cm}^{-1}$ are due to $\mathrm{C}-\mathrm{N}$ stretching vibrations of the metal complexes.

\section{Electronic spectra and magnetic moments}

The electronic spectra provide the information about the electronic structure of the synthesized ligand and its metal complexes. The UV-Visible spectrum clearly shows the electronic absorption of HTF ligand and its metal complexes which are shown in Figure 2. The electronic spectra of all the metal complexes exhibited different bands in the region $250-300 \mathrm{~nm}$ and $450-490 \mathrm{~nm}$. The band appearing in the range of $250-300 \mathrm{~nm}$ is assigned as $\pi \rightarrow \pi^{*}$ transition of the ligand where as the band at $450-490 \mathrm{~nm}$ is assigned to chromophores metal complexes which is clear evidence the metal ion coordination with nitrogen and oxygen atom present in 1-(8-hydroxy quinolin-2yl-methyl) thiourea ligand. The electronic spectrum of HTF-Co complex exhibited the absorption at $20,630 \mathrm{~cm}^{-1}$. The electronic transition of HTF-Co observed between ${ }^{2} \mathrm{E}_{\mathrm{g}} \rightarrow{ }^{2} \mathrm{~T}_{2 \mathrm{~g}}$. The structure of HTF-Co was assigned as square bipyramidal environment with a magnetic moment of $1.79 \mathrm{BM}$. The absorption bands occurred at $19,867 \mathrm{~cm}^{-1}$ is assigned as ${ }^{3} \mathrm{~A}_{2 \mathrm{~g}} \rightarrow{ }^{3} \mathrm{~T}_{1 \mathrm{~g}}$ for tetrahedral HTF-Ni complex with a magnetic moment value of $3.10 \mathrm{BM}$.
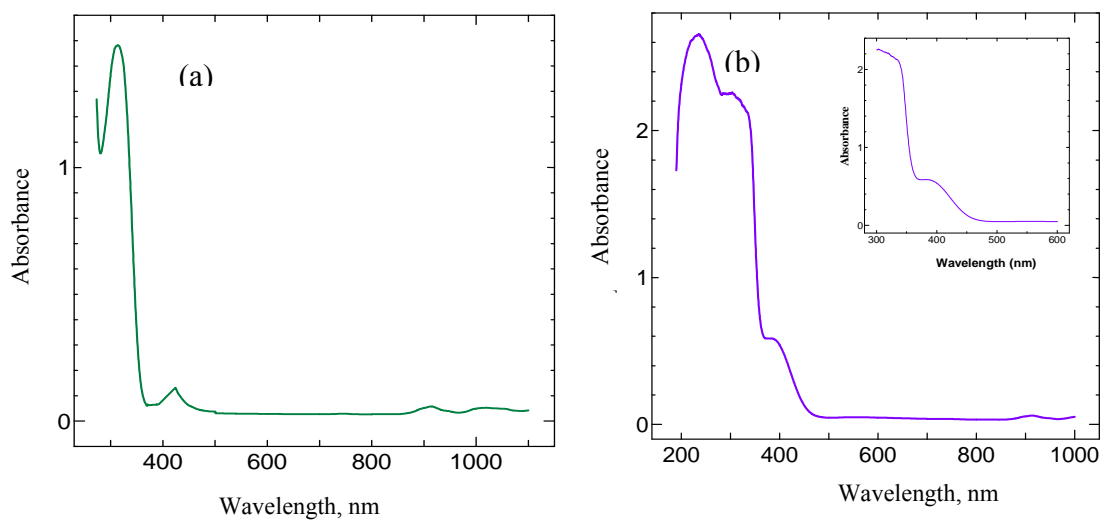

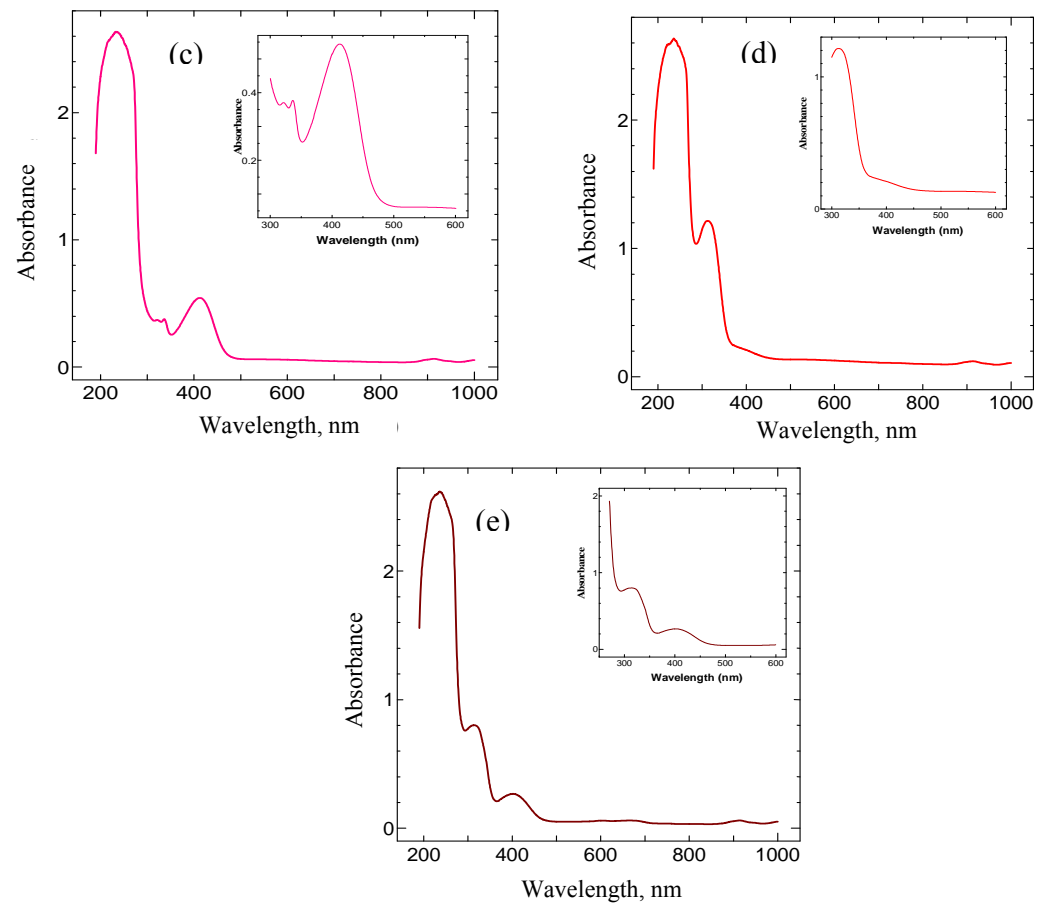

Figure 2. UV-Visible absorption spectra obtained for (a) HTF-ligand, (b) HTF-Zn, (c) HTF$\mathrm{Cu}$, (d) HTF-Ni and (e) HTF-Co complexes.

\section{NMR spectral analysis}

The ${ }^{1} \mathrm{H}$ NMR spectrum of the HTF ligand and its metal complexes are shown in Figure 3 and the spectral data are presented in Table 3. The signal at $8.6 \mathrm{ppm}$ is assigned to the $\mathrm{OH}$ group of 8-hydroxyquinoline ring and this downfield shift is due to intramolecular hydrogen bonding between $\mathrm{OH}$ of 8 -hydroxyquinoline ring. The signal at $8.86 \mathrm{ppm}$ is assigned to $\mathrm{NH}_{2}$ group of thiourea moiety. The signal in the region of 7.1-7.6 ppm is assigned to all the aromatic protons of the 8 -hydroxyquinoline ring ${ }^{19}$. The signal appearing in the region of $3.4 \mathrm{ppm}$ is due to methylene protons attached with 8-hydroxyquinoline ring. The signal obtained at $2.3 \mathrm{ppm}$ is attributed to $\mathrm{NH}$ group in thiourea moiety.

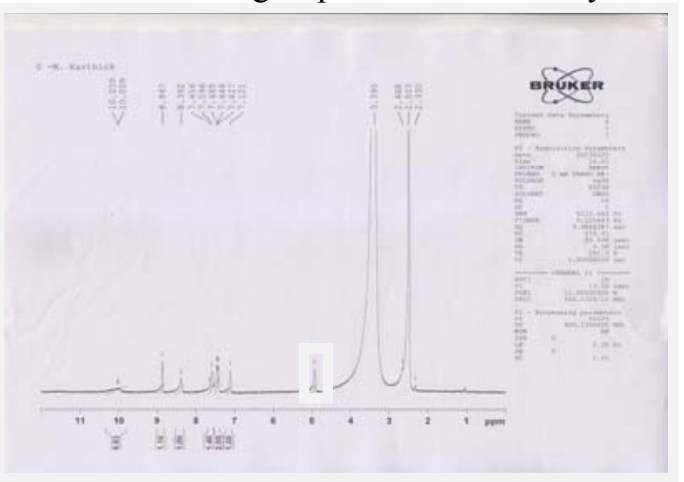

Figure 3. ${ }^{1} \mathrm{H}-\mathrm{NMR}$ spectrum obtained for HTF-ligand 
Table 3. ${ }^{1} \mathrm{H}$ NMR spectral data of the ligand and their complexes

\begin{tabular}{cccc}
\hline & \multicolumn{3}{c}{ Chemical Shifts, ppm } \\
\hline & Aromatic protons & $\mathrm{CH}_{2}$ attached with 8-HQ & $\mathrm{NH}_{2}$ of thiourea moiety \\
\hline HTF-ligand & $7.1-7.6$ & $2.3-5.0$ & 8.86 \\
HTF-Zn & $7.1-7.4$ & 4.0 & 8.80 \\
HTF-Cu & $7.1-7.4$ & 4.0 & 8.80 \\
HTF-Ni & $7.1-7.4$ & 4.0 & 8.80 \\
HTF-Co & $7.1-7.4$ & 4.0 & 8.80 \\
\hline
\end{tabular}

The ${ }^{1} \mathrm{H}$ NMR spectra of the organic metal complexes show multiplet in the range at 7.1-7.4 ppm are assigned to the aromatic protons. The signal observed in the region $4.0 \mathrm{ppm}$ is due to methylene protons. The signal obtained in the region of $8.6 \mathrm{ppm}$ is assigned to $\mathrm{OH}$ group of HTF ligand and its complexes which is completely vanished from its parent ligand gives a clear evidence for the bond formation of metal ion with the ligand through the oxygen atom of the -OH group in the quinoline ring (Figure 4).

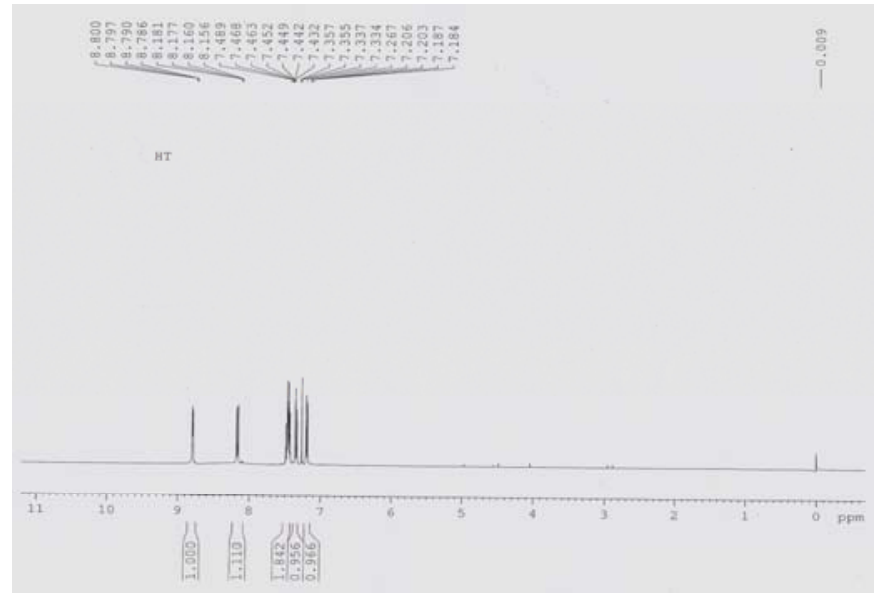

Figure 4. ${ }^{1} \mathrm{H}-\mathrm{NMR}$ spectrum obtained for HTF-Ni complex

The ${ }^{13} \mathrm{C}$ NMR spectrum of the HTF ligand is shown in Figure 5. The observed chemical shifts are assigned on the basis of the literature ${ }^{20}$. The spectrum shows the corresponding peaks at 109.96, 117.8, 127.8, 128.5, 136.1 and $130.3 \mathrm{ppm}$ with respect to $\mathrm{C} 1$ to $\mathrm{C} 9$ of the 8-hydroxyquinoline ring. The peak appeared at $56.2 \mathrm{ppm}$ is assigned to $\mathrm{CH}_{2}$ group is attached with 8 -hydroxyquinoline ring. The peak is assigned at $180.0 \mathrm{ppm}$ is assigned $\mathrm{C}=\mathrm{S}$ which is present in thiourea moiety. The mass spectrum of the synthesized HTF-ligand shows molecular ion peak at $\mathrm{m} / \mathrm{z} 233$ indicating the molecular weight of HTF-ligand.

\section{Electrochemical behavior of HTF ligand and its metal complexes}

The electrochemical behaviour of HTF-ligand and its metal complexes were examined by cyclic voltammetry based on the literature ${ }^{21-23}$. Cyclic voltammogram $(\mathrm{CV})$ of the HTFligand and its metal complexes are shown in Figure 6. Figure 6a shows the CV obtained for the HTF-ligand in DMF solution using GCE as a working electrode. It shows three pairs of oxidation along with one shoulder oxidation wave. The redox wave I at $-0.72 \mathrm{~V}$ corresponds to the quinoline redox. The redox wave II at $0.65 \mathrm{~V}$ corresponds to the aldehyde redox wave. The oxidation wave at $0.45 \mathrm{~V}$ is due to the amine oxidation. Figure $6 \mathrm{~b}$ shows the quinone redox wave at $-0.82 \mathrm{~V}$ and one broad oxidation wave at $0.21 \mathrm{~V}$ corresponding to the metal 
redox wave $\mathrm{Zn}^{\mathrm{II}} / \mathrm{Zn}^{\mathrm{I}}$. The absence of oxidation wave at $0.63 \mathrm{~V}$ indicates that the metal ion forms a bond on keto group. Figure $6 \mathrm{c}$ shows the $\mathrm{CV}$ for HTF-Cu complex. It shows a redox wave at $-0.72 \mathrm{~V}$ indicating the presence of quinoline moiety in metal complex. Further, it shows a weak oxidation wave at $0.14 \mathrm{~V}$ corresponding to $\mathrm{Cu}^{\mathrm{II}} / \mathrm{Cu}^{\mathrm{I}}$ metal centre ${ }^{24}$. This clearly reveals the formation of HTF-Cu complex. Based on the results, the following structures are assigned to the complexes prepared (Scheme 2). These structures are in agreement with the structures proposed by Markus Albrecht et al. ${ }^{15}$.

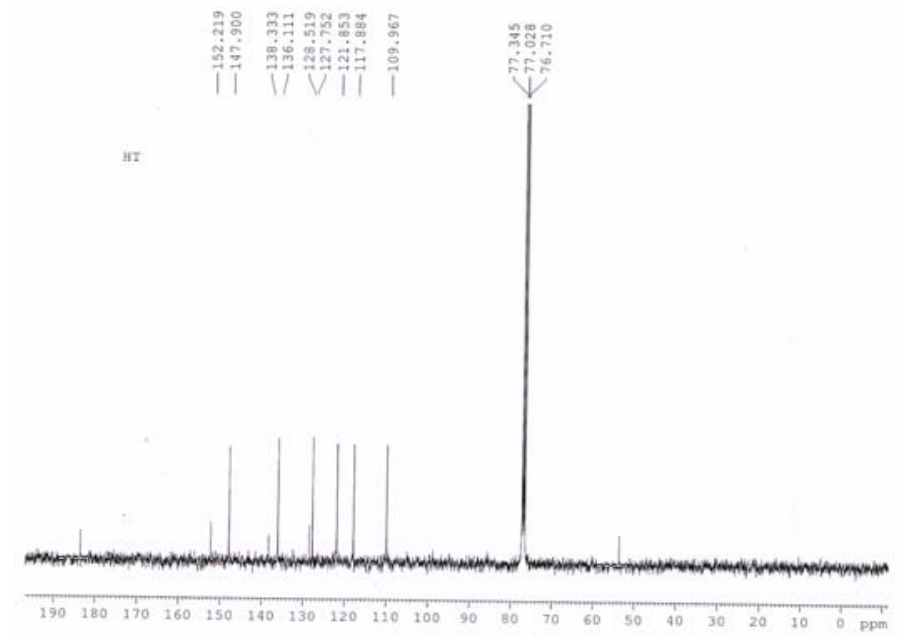

Figure 5. ${ }^{13} \mathrm{C}$-NMR spectrum obtained for HTF-ligand
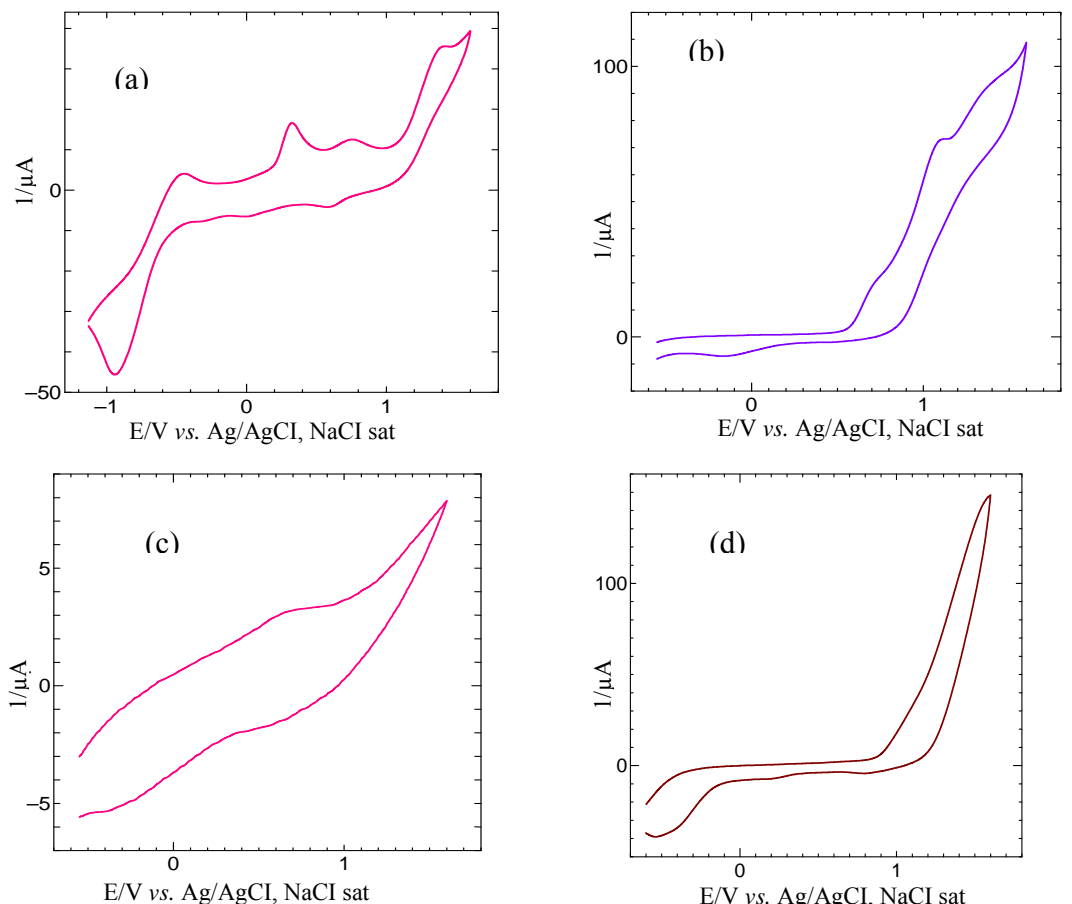


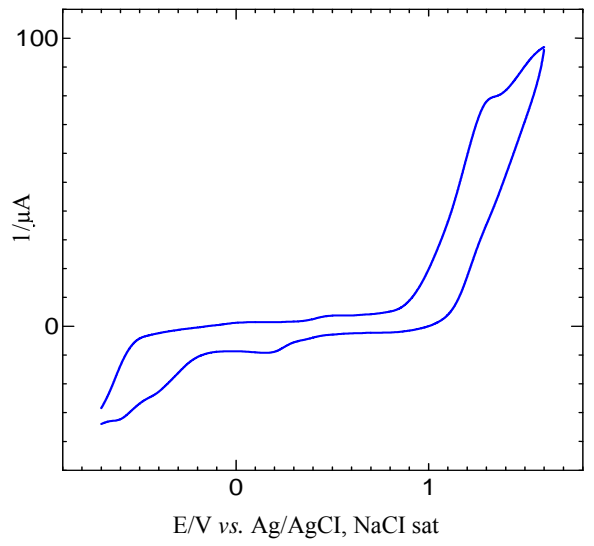

Figure 6. CVs obtained for (a) HTF-ligand, (b) HTF-Zn, (c) HTF-Cu, (d) HTF-Ni and (e) HTF-Co complexes

\section{Antimicrobial screening}

The results of microbial screening of the HTF ligand and its metal complexes are presented in Table 4.

Table 4. Antibacterial activity of HTF-ligand and its metal complexes

\begin{tabular}{lcccc}
\hline \multicolumn{1}{c}{ Compound } & \multicolumn{4}{c}{ Zone inhibition, mm } \\
\hline HTF-ligand & E.coli & S.aureus & P.aeruginosa & C.tropicalis \\
HTF-Zn & 14 & 16 & 22 & 11 \\
HTF-Cu & 15 & 17 & 22 & 14 \\
HTF-Ni & 16 & 18 & 24 & 13 \\
HTF-Co & 15 & 17 & 22 & 13 \\
Standard (Ciprofloxacin) & 16 & 15 & 19 & 11 \\
Control(DMF) & 15 & 15 & 20 & 12 \\
\hline
\end{tabular}

\section{Antibacterial activity}

The 1-(8-hydroxy quinolin-2yl-methyl) thiourea ligand and its metal complexes show good inhibition against the growth of pathogenic bacterial strains. A good result was obtained for the HTF-Cu, HTF-Co complexes against S.aureus, E.coli, P.aeruginosa and C.tropicalis. HTF-Cu and HTF-Co complexes show higher activity against S.aureus when compared to the 1-(8-hydroxy quinolin-2yl-methyl) thiourea ligand and other complexes. The 1-(8-hydroxy quinolin-2yl-methyl) thiourea ligand, HTF-Zn, HTF-Cu, HTF-Ni complexes show activity against E.coli.

\section{Conclusion}

Four number of metal complexes have been prepared using a synthesized 1-(8-hydroxy quinolin-2yl-methyl) thiourea ligand involving 8-hydroxyquinoline and thiourea with formaldehyde. The synthesized ligand and its four metal complexes show higher bacterial activity against S.aureus, E.coli, P.aeruginosa and C.tropicalis. The activity of ligand and its metal complexes are greater than the standard chosen for the study. 


\section{References}

1. (a) Jirf S, Anal Chim Acta., 1963, 28, 132; (b) Hollingshead R G W, Oxine and its Derivatives, Butters-Worths, London, 1954.

2. Leung L M, Lo W Y, So S K, Lee K M and Choi W K, J Am Chem Soc., 2000, 122(23), 5640-5641; DOI:10.1021/ja000927z.

3. Zhang J, Xiong R G, Chen Z F, You X Z, Lee G H and Peng S M, Chem Lett., 2001, 30(7), 676-677; DOI:10.1246/cl.2001.676.

4. Albrecht M, Blau $O$ and Frohlich R, Chem Eur J., 1999, 5(1), 48-56; DOI:10.1002/(SICI)1521-3765(19990104)5:1<48::AID-CHEM48>3.0.CO;2-7.

5. Merritt L L, Cady R T and Mundy B W, Acta Crystallogr., 1954, 7(6-7), 473-476; DOI:10.1107/S0365110X54001491.

6. Kai Y, Morita M, Yasuoka N and Kasai N, Bull Chem Soc Jpn., 1985 , 58(6), 1631-1635; DOI:10.1246/bcsj.58.1631.

7. Dziwinski E, Cote G, Bauer D and Szymanowski J, Hydrometallurgy, 1995, 37(2), 243-250; DOI:10.1016/0304-386X(94)00022-U.

8. Czugler M, Neumann R and Weber E, Inorg Chim Acta., 2001, 313(1-2), 100-109; DOI:10.1016/S0020-1693(00)00367-4.

9. (a) Thomas F, Baret P, Imbert D, Pierre J L and Serratrice G, Bioorg Med Chem Lett., 1999, 9(20), 3035-3040; DOI:10.1016/S0960-894X(99)00527-2; (b) Carris C, Baret P,

Pierre J L and Serratrice G, Tetrahedron, 1996, 52(13), 4659-4672; DOI:10.1016/0040-4020(96)00166-4; (c) Serratrice G, Boukhalfa H, Beguin C, Baret P, Carris C and Pierre J L, Inorg Chem., 1997, 36(18), 3898-3910; DOI:10.1021/ic9608096; (d) Prodi L, Bargossi C, Montalti M, Zaccheroni N, Su N, Bradshaw J S, Izatt R M and Savage P B, J Am Chem Soc., 2000, 122(28), 67696770; DOI:10.1021/ja0006292; (e) Su N, Brashaw J S, Zhang X X, Song H, Savage P B, Xue G, Krakowiak K E and Izatt R M, J Org Chem., 1999, 64(24), 8855-8861; DOI:10.1021/jo991081o; (f) Hayashi M, Ishii M, Hiratani K and Saigo K, Tetrahedron Lett., 1998, 39(34), 6215-6218; DOI:10.1016/S0040-4039(98)01277-5.

10. Albrecht M, Blau O, Witt K, Wegelius E, Nissinen M, Rissanen K and Frohlich R, Synthesis, 1999, 1999(10), 1819-1829; DOI:10.1055/s-1999-3599.

11. (a) Albrecht M, Witt K, Wegelis Eu, Nissinen M and Rissanen K, Tetrahedron, 2000, 56(4), 591-594; DOI:10.1016/S0040-4020(99)01057-1; (b) Albrecht M, Witt K, Frohlich R and Kataeva O, Tetrahedron, 2002, 58(3), 561-567;

DOI:10.1016/S0040-4020(01)01168-1.

12. Christopher M Cheatum, Max M Heckscher and Fleming Crim F, Chem Phys Lett., 2001, 349(1-2), 37-42.

13. Tang C W, Van S A, Slyke, Appl Phys Lett., 1987, 51, 913.

14. Chen C H and Shi J M, Coord Chem Rev., 1998, 171, 161-174; DOI:10.1016/S00108545(98)90027-3.

15. Markus Albrecht, Karen Witt, Patrick Weis, Elina Wegelius and Roland Frohlich, Inorganica Chimica Acta, 2002, 341, 25-32; DOI:10.1016/S0020-1693(02)01201-X.

16. Silverstein R M and Webster F X Spectrometric Identification of Organic Compounds, $6^{\text {th }}$ Ed., John Wiley \& Sons, Inc., New York., 1998, 217.

17. Singru R N, Zade A B and Gurunule W B, J Appl Plym Sci., 2008, 109(2), 859-868; DOI:10.1002/app.28197.

18. Nakanishi K. Infra Red Absorption Spectroscopy Practical. Golden Day, Inc and Nankoda Co.Ltd., Tokyo, 1967. 
19. Raj J A, Vedhi C, Burkanudeen A, Arumugam P and Manisankar P, Ionics, 2010, 16(2), 171-175; DOI:10.1007/s11581-009-0328-2.

20. Pretsch E, Bulhlmann P and Affolter C, Structure Determination of Organic Compounds. Springer-Verlag Heidelberg., New York, 2000.

21. Gallardo I, Pinson J, Vila N, J Phys Chem., B, 2006, 110(39), 19521-19529.

22. Bard A J and Faulkner L R, Elactrochemical Methods: Fundamentals and Applications, $2^{\text {nd }}$ Ed., John Wiley, New York., 2000.

23. Obini J, Bedioui F and Nyokong T, J Electroana Chem., 2005, 576, 323-332.

24. Sandhanamalar D, Vedanayaki S and Rajavel R, Chem Sci Trans., 2013, 2(2), 529-537; DOI:10.7598/cst2013.332. 